\title{
Genetic Analysis of Glutamate-Oxaloacetate Transaminase Isozymes in Wild Species in Section Cepa of Allium
}

\author{
Yosuke Tashiro, Masayoshi Shigyo, Takayuki Mizutani* and Sadami Miyazaki \\ Faculty of Agriculture, Saga University, Saga 840
}

\begin{abstract}
Summary
Glutamate-oxaloacetate transaminase (GOT) was studied to establish the genetic system of GOT isozymes in the wild species in section Cepa of Allium. From the results of isozyme analyses using two cultivated species (A. fistulosum. A. cepa Aggregatum group), three wild species (A. vavilovii, A. oschaninii, A. galanthum), one hybrid between $A$. fistulosum and $A$. cepa Aggregatum group and six hybrids between the cultivated and wild species, it was revealed that 1 ) the three wild species possessed the two GOT gene loci (Got-1, Got-2) in common with $A$. fistulosum and $A$. cepa, 2) two alleles were detected at Got-1 and three alleles at Got.2, 3) A. fistulosum possessed Got-1 $1^{F}$ and Got- $2^{F}$ and A. cepa Aggregatum group had Got- $1^{A}$ and Got- $2^{A}$, and 4) A. vavilovii possessed Got- $1^{A}$ and Got- $2^{A}$; A. oschaninii had Got-1 ${ }^{A}$ and Got- $2^{F} ;$ A. galanthum had Got- $1^{A}$ and Got- $2^{G}$. These conclusions indicate that the GOT isozyme genes are useful genetic markers in the wild species in section Cepa.
\end{abstract}

\section{Introduction}

Allium vavilovii M. Pop. et Vved., A. oschaninii O. Fedtsch. and A. galanthum Kar. et Kir. are known as the wild species in section Cepa of Allium (McCollum, 1976; Traub, 1968; Wendelbo, 1971). These wild species seem to be important genetic resources for improving the cultivated species in section Cepa. It is necessary to establish genetic markers in these species for their practical utilization.

Isozyme gene is one of the useful genetic markers because of the co-dominant expression (Moore and Collins, 1983). In the cultivated species of section Cepa, genetic analyses of isozymes of many enzymes have been carried out, especially on the glutamate-oxaloacetate transaminase (GOT) as follows. Halijah and Raniah (1990) reported intra. specific polymorphisms observed in four cultivars of $A$. cepa. From the results of $\mathrm{BC}_{1}$ analyses of

Received for publication 22 August 1994.

A part of this study was presented at the 1991 Autumn Meeting of the Japanese Society for Horticultural Science, Hokkaido.

*Present address : Faculty of Agricuture, Kyusyu Tohkai University, Chouyou-mura, Aso-gun, Kumamoto 869-14
GOT isozymes in the hybrids between $A$. fistulosum and $A$. cepa common onion group, Van der Valk et al. (1991) reported two gene loci (Got-1. Got-2) which appeared to be unlinked. There was no linkage between an acid phosphatase gene locus (Acp-1) and Got-2 in A. fistulosum (Haishima and Ikehashi, 1992). Haishima et al. (1993) recognized that there were intraspecific polymorphisms in 13 cultivars of $A$. fistulosum. Shigyo et al. (1994) determined chromosomal locations of the GOT isozyme genes in $A$. fistulosum and $A$. cepa Aggregatum group by means of isozyme analysis of alien monosomic addition lines between these species. Consequently, gene locus Got-2 was located on the homoeologous sub-telocentric chromosomes, $6 \mathrm{~F}$ in A. fistulosum and 6A in $A$. cepa aggregatum group, and gene locus Got-1 was on the other chromo. somes. Although many observations mentioned above had been reported, the genetic analysis of the GOT isozymes in the wild species had not been conducted.

In the present study, GOT isozyme analysis was performed to establish the GOT genetic systems of the wild species in section Cepa. 


\section{Materials and Methods}

The following plants were used; Japanese bunching onion (A. fistulosum), shallot (A. cepa aggregatum group), A. vavilovii, A. oschaninii, A. galanthum, hybrid between $A$. fistulosum and $A$. cepa Aggregatum group, hybrids between $A$. fistulosum and each of the wild species, and hybrids between A. cepa Aggregatum group and each of the wild species (Table 1).

Table 1. List of plant materials.

\begin{tabular}{lll}
\hline \hline \multirow{2}{*}{ Species } & $\begin{array}{l}\text { Cultivar name, accession no. } \\
\text { or cross combination }\end{array}$ & genome ${ }^{z}$ \\
\hline Allium fistulosum & 'Kujyo' & FF \\
A. cepa Aggregatum group & 'Chiang mai' & AA \\
A. vavilovii & $83010^{y}$ & VV \\
A. oschaninii & $78227^{y}$ & OO \\
A. galanthum & $65447^{y}$ & GG \\
Hybrid & 'Kujyo' $\times$ 'Chiang mai' & AF \\
& $83010 \times$ 'Kujyo' & FV \\
& $78227 \times$ 'Kujyo' & FO \\
& $65447 \times$ 'Kujyo' & FG \\
& $83010 \times$ 'Chiang mai' & AV \\
& $78227 \times$ 'Chiang mai' & AO \\
& $65447 \times$ 'Chiang mai' & AG \\
\hline
\end{tabular}

$\therefore \mathrm{F}$ and $\mathrm{A}$; Tashiro (1984), V, O and $\mathrm{G}$; denoted in the present study for the genomes of $A$. vavilovii. $A$. oschaninii, A. galanthum, respectively.

${ }^{y}$ Accessions from IVT (CPRO) of the Netherlands.
Young expanding leaves were used for enzyme extraction. All processes of the extraction, polyacrylamide slab gel electrophoresis and enzyme activity staining for glutamate-oxaloacetate trans. aminase (GOT; EC 2.6.1.1) were carried out according to the method suggested by Hirai (1988).

\section{Results and Discussion}

The band patterns of GOT isozyme clearly showed an interspecific polymorphism among the species used in this study (Figs. 1 and 2). From the results of GOT isozyme analysis in A. fistulosum, A. cepa and their hybrids by Van der Valk et al. (1991) and Shigyo et al. (1994), a polymor. phism between these two species was already confirmed. In the wild species used in the present study, A. vavilovii showed the same band pattern as that of $A$. cepa Aggregatum group, while the band patterns of $A$. oschaninii and $A$. galanthum were different form both of $A$. fistulosum and $A$. cepa Aggregatum group. In $A$. oschaninii, the cathodal band (band 3 in Fig. 2) had the same migration position as the cathodal band of $A$. cepa Aggregatum group, and the anodal band (band 7) had the same migration position as the anodal band of $A$. fistulosum. In $A$. galanthum, the cathodal band (band 3) had the same migration position as the cathodal band of $A$. cepa Aggregatum group, and the anodal band (band 4) was

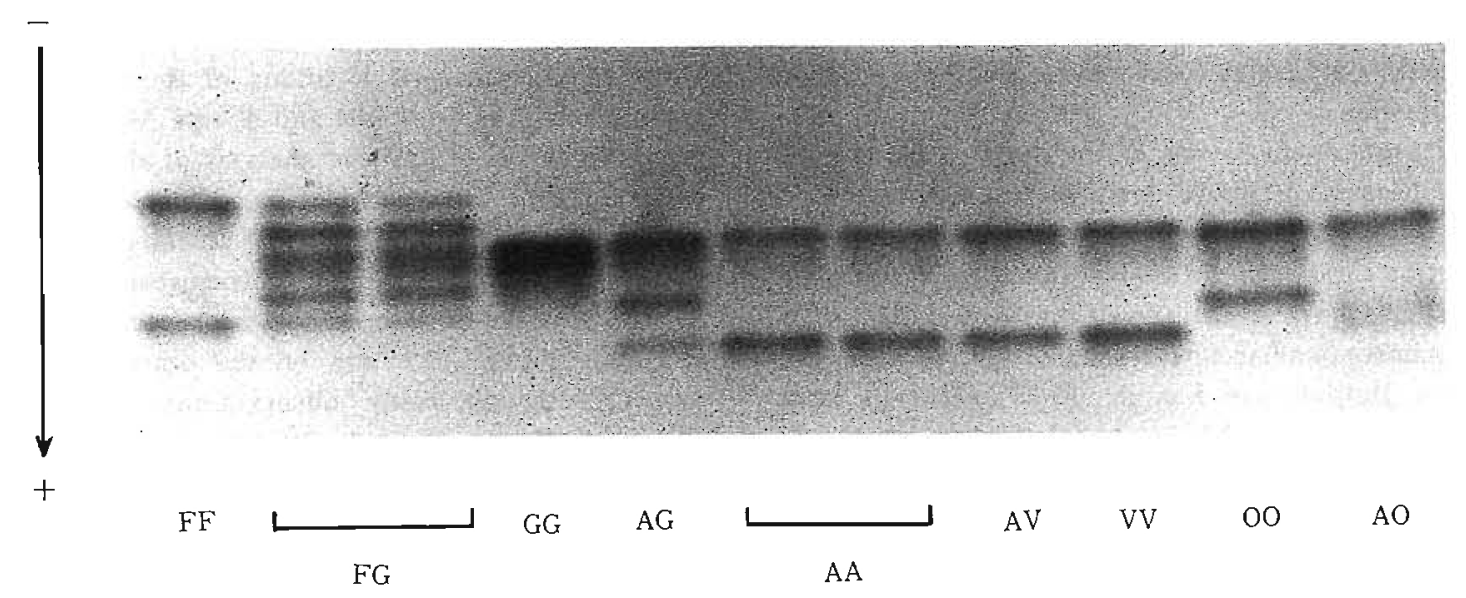

Fig. 1. GOT zymograms of A. fistulosum (FF), hybrid between A. fistulosum and A. galanthum (FG), A. galanthum (GG), hybrid between $A$. cepa Aggregatum group and A. galanthum (AG), A. cepa Aggregatum group (AA), hybrid between A. cepa Aggregatum group and A. vavilovii (AV). A. vavilovii (VV), A. oschaninii (OO) and hybrid between $A$. cepa Aggregatum group and $A$. oschaninii (AO). 


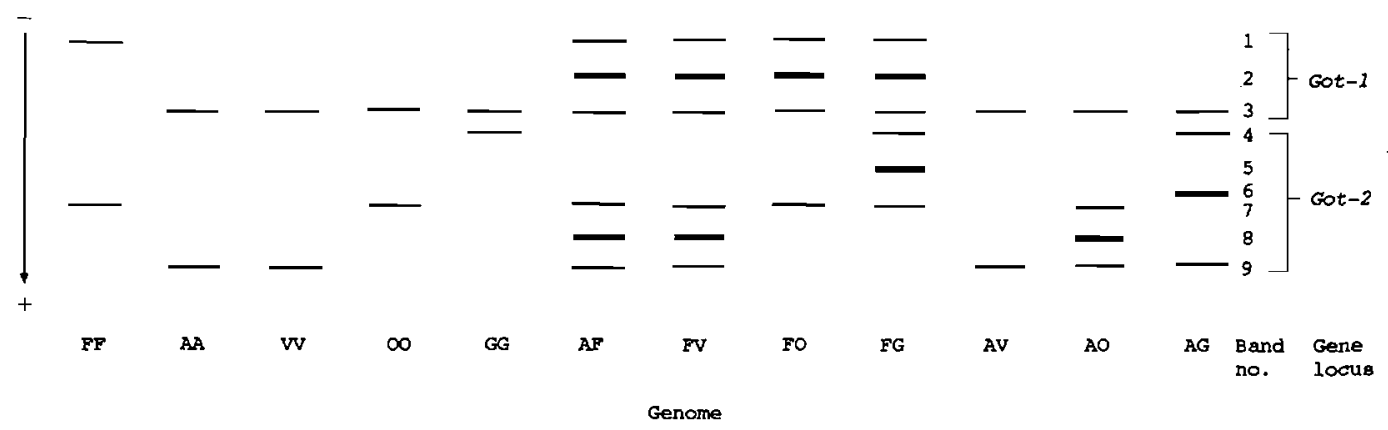

Fig. 2. Schematic illustration of GOT zymograms of A. fistulosum (FF), A. cepa Aggregatum group (AA), A. vavilovii (VV), A. oschaninii (OO), A. galanthum (GG), and their hybrids (AF, FV, FO, FG, AV, AO, AG).

Table 2. Subunit constitution, gene locus and allele of GOT isozyme band in section Cepa of Allium.

\begin{tabular}{|c|c|c|c|}
\hline Band no. & Subunit constitution & Gene locus & Allele \\
\hline 1 & $\alpha \alpha$ & Got-1 & $\operatorname{Got} \cdot 1^{F}$ \\
\hline 2 & $\alpha \beta$ & Got.1 & Got-1 ${ }^{F}, \operatorname{Got}-1^{A}$ \\
\hline 3 & $\beta \beta$ & Got-1 & $\operatorname{Got}-1^{A}$ \\
\hline 4 & $\gamma \gamma$ & Got-2 & Got $-2^{G}$ \\
\hline 5 & $\gamma \delta$ & Got-2 & Got $-2^{F}$, Got $-2^{G}$ \\
\hline 6 & $\gamma \varepsilon$ & Got-2 & Got $-2^{A}$, Got $-2^{G}$ \\
\hline 7 & $\delta \delta$ & Got-2 & Got- $Z^{F}$ \\
\hline 8 & $\delta \varepsilon$ & Got-2 & $\operatorname{Got} \cdot 2^{F}, \operatorname{Got} \cdot 2^{A}$ \\
\hline 9 & $\varepsilon \varepsilon$ & Got-2 & $\operatorname{Got} \cdot 2^{A}$ \\
\hline
\end{tabular}

close to the cathodal band and was species specific.

In the hybrid (AF, FV), in addition to the four bands derived from parents (bands $1,3,7,9$ ) two more bands (bands 2,8 ) were detected. In the hybrid ( $\mathrm{FO}$ ), in addition to the three parental bands (bands $1,3,7$ ) an extra band (band 2) was detected. In the hybrid ( $F G$ ), in addition to the four parental bands (bands $1,3,4,7$ ) two more bands (bands 2,5 ) were detected. In the hybrid (AV), only the two parental bands (bands 3,9 ) were detected. In the hybrid ( $\mathrm{AO}$ ), in addition to the three parental bands (bands $3,7,9$ ) an extra band (band 8) was detected. In the hybrid (AG), in addition to the three parental bands (bands $3,4,9$ ) an extra band (band 6) was detected. The band 2 migrated to an intermediate position between the bands 1 and 3 , the band 5 between the bands 4 and 7 , the band 6 between the bands 4 and 9 , and the band 8 between the bands 7 and 9 . Further, in all diploid hybrids, the additional bands (bands $2,5,6$, 8) were stained more intensely than the parental bands (bands $1,3,4,7,9$ ).
These results from isozyme analyses of interspecific hybrids indicate the following : 1) There are five kinds of subunits $(\alpha, \beta, \gamma, \delta, \varepsilon)$ of the GOT enzyme proteins in the species of section Cepa used in the present study. 2) Bands 1, 3, 4, 7 and 9 are homodimeric enzymes. 3) Bands 2, 5, 6 and 8 are heterodimeric enzymes. 4) The two cultivated and three wild species used in this study have two common gene loci (Got-1, Got-2). 5) There are two alleles $\left(\right.$ Got $-1^{F}$, Got $\left.-1^{A}\right)$ at Got-1 and three alleles (Got-2F, Got-2A, Got-2 ${ }^{G}$ ) at Got-2, 6) A. fistulosum has Got- $1^{F}$ and Got. $2^{F}$ at the two loci. 7) A. cepa aggregatum group and $A$. vavilovii have Got- $A^{A}$ and Got- $2^{A}$. 8) A. oschaninii has Got- $1^{A}$ and Got- $2^{F}$. 9) A. galanthum has Got $1^{A}$ and Got- $2^{G}$. Based on the above analyses, the subunit constitutions, gene loci and alleles of GOT isozyme bands in Fig. 2 are summarized in Table 2. Furthermore, genotypes of the species used in this study are shown in Table 3 .

Previous studies on the GOT isozymes in $A$. fistulosum and $A$. cepa had suggested the existences 
Table 3. Genotype of gene loci Got-1 and Got-2 in the species of section Cepa in Allium .

\begin{tabular}{|c|c|c|}
\hline \multirow{3}{*}{ Species } & \multicolumn{2}{|c|}{ Genotype } \\
\hline & \multicolumn{2}{|c|}{ Gene locus } \\
\hline & Got-1 & Got.2 \\
\hline A. fistulosum & Got $-1^{F} / G o t-1^{F}$ & $G o t \cdot 2^{F} / G o t \cdot 2^{F}$ \\
\hline A. cepa Aggregatum group & $\operatorname{Got} \cdot 1^{A} / \operatorname{Got} \cdot 1^{A}$ & Got $-2^{A} /$ Got $-2^{A}$ \\
\hline A. vavilovii & $\operatorname{Got}-1^{A} / \operatorname{Got}-1^{A}$ & Got $-2^{A} /$ Got $-2^{A}$ \\
\hline A. oschaninii & $\operatorname{Got} \cdot 1^{A} / \operatorname{Got} \cdot 1^{A}$ & $\operatorname{Got} \cdot 2^{F} / \mathrm{Got} \cdot 2^{F}$ \\
\hline A. galanthum & $\operatorname{Got}-1^{A} / \operatorname{Got}-1^{A}$ & $G o t-2^{G} / G o t-2^{G}$ \\
\hline
\end{tabular}

of the alleles Got- $1^{F}$ and Got-1 ${ }^{A}$ at Got-1, and Got$2^{F}$ and Got-2A at Got-2 (Van der Valk et al., 1991; Shigyo et al., 1994). In the present study, the allele Got- $2^{G}$ was newly recognized in a wild species, A. galanthum. According to the different combinations of the two alleles at Got-1 and the three alleles at Got-2, the interspecific polymorphisms were exhibited among the species of section Cepa used in this study. The GOT isozyme genes were available for the identifications of hybrids used in this study except the hybrid between $A$. cepa Aggregatum group and A.vavilovii. These isozyme genes are expected to serve as useful genetic markers for the genetics and practical utilization of the wild species in section Cepa.

\section{Acknowledgments}

The authors are grateful to Drs. Q. P. van der Meer and J. N. de Vries for the kind gift of wild Allium species. The authors wish to thank Mr. Y. Kosugi for his contribution to this study. The authors further express thier gratitude to Dr. V. V. R. N. Sastry of Saga University for reviewing the manuscript.

\section{Literature Cited}

Haishima, M. and H. Ikehashi. 1992. Identification of isozyme genes in native varieties of Japanese bunching onion (Allium fistulosum L.). Japan. J. Breed. 42 : 497-505.

Haishima, M. J. Kato and H. Ikehashi. 1993. Isozyme polymorphism in native varieties of Japanese bunching onion (Allium fistulosum L.). Japan. J. Breed. $43: 537-547$.

Halijah, I. and H. J. Mit Raniah. 1990. Isozyme variations of some edible Alliums. Malays. Appl. Biol. $19: 23-28$

Hirai, M. 1988. Isozyme analysis of plant. p. 95-99. In : S. Higuchi (ed.). In vitro culture of horticultural plant. Shibata Hario Garasu Co., Ltd., Tokyo. McCollum, G. D. 1976. Onion and allies. p. 186-190. In : N. W. Simmonds (ed.). Evolution of crop plants. Longman, London.

Moore, G. A. and G. B. Collins. 1983. New challenges confronting plant breeding. p. $25-58$. In : S. D. Tanksley and T.J. Orton (eds.). Isozymes in plant genetics and breeding. Part A. Elsevier, Amsterdam.

Shigyo, M., Y. Tashiro and S. Miyazaki. 1994. Chromosomal locations of glutamate oxaloacetate transaminase gene loci in Japanese bunching onion (Allium fistulosum L.) and shallot (A. cepa L. Aggregatum group). Japan. J. Genet. 69 : 417-424.

Tashiro, Y. 1984. Genome analysis of Allium wakegi Araki. J. Japan. Soc. Hort. Sci. 52 : 399-407.

Traub, H. P. 1968. The subgenera, sections and subsections of Allium. Plant Life 24 : 147-163.

Van der Valk, P., C. Verstappen, F. Kik., J. T. Everink and J. N. de Vries. 1991. Independent segregation of two isozyme markers and inter-plant differences in nuclear DNA content in the interspecific backcross (Allium fistulosum L. $\times A$. cepa L.) $\times A$. cepa L. Euphytica 55 : 151-156.

Wendelbo, P. 1971. Alliaceae. p. 1-100. In : K. H. Rechinger (ed.). Flora Iranica. Akademische Druck-u. Verlagsanstalt, Graz, Austria. 
ネギ属Cepa 節野生種のグルタミン酸-オキサロ酢酸トランスアミナーゼアイソザイムの

\section{遺伝分析}

田代洋丞·執行正義・水谷高幸* · 宮崎貞巳

佐賀大学農学部 840 佐賀市本庄町 1

摘 要

ネギ属Cepa 節野生種のグルタミン酸-オキサロ酢酸 トランスアミナーゼ（GOT）の遺伝系を明らかにす るためにアイソザイムの分析を行った，ネギ，シャロ ット, 両者の雑種, 野生種 (A. vavilovii, A. oschaninii，A. galanthum) およびネギ, シャロットと各野 生種の雑種を分析した結果, これらの野生種はネギお よびシャロットと共通な GOT 遺伝子座 Got.1 お方び Got-2 を持ち，Got-1 上には二つの対立遺伝子 (Got-1 $1^{F}$, Got-1 $\left.{ }^{A}\right)$ が，Got.2 上には三つの対立遺伝子（Got-2 $2^{F}$,

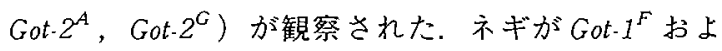
びGot-2 $2^{F}$ を持ち，シャロットが Got-1 ${ }^{A}$ および Got-2 $2^{A}$ を持っていたのに対し，A，vavilovii は Got-1 $1^{A}$ おる゙ Got-2 $2^{A}$ を, A. oschaninii は Got-1 $1^{A}$ およびGot-2 $2^{F}$ を, A. galanthum はGot. $1^{A}$ およびGot-2 $2^{G}$ を持っていた。 これらのことにより，GOTアイソザイム遺伝子は Cepa 節野生種の有用な遗伝的マーカーであることが 分かった。

*現在：九州東海大学農学部 